\title{
Research on the new mode of student management of University Counselors under the new situation
}

\author{
Yu Ji \\ League Committee \\ Hebei Institute of Mechanical and Electronic Technology \\ Xingtai,China
}

\begin{abstract}
With the rapid development of economy and society of our country, China's higher education from elite oriented to mass change, the adjustment on College Counselors of student management model to adapt to the new form of. At first in this paper the mode of "education, management, service and development", and then analyzed the connotation of a new model for the management of students and the principles, characteristics, at last, the paper introduces the new pattern of student management system. This new student management mode in the guarantee of the social for the talent macro, but also give full plays to the initiative of the students, so that students can achieve long-term balanced development.
\end{abstract}

Key words: new mode of student management, the new situation, the "people-oriented

\section{INTRODUCTION}

Education and management work in Colleges and universities, students management work is an important part of it consists of the culture, education, politics, the economy and so on, and these elements for the growth of college students plays a very important role.

However, for a long time, the management of our country's universities is mainly the mode of education management. However, this model did not full of students in the individual's independence, difference, thus greatly reducing the effect and purpose of education management in Colleges and universities. So, the reform of college students management mode becomes a very important issue.. In recent years, relevant education departments and colleges began to gradually pay attention to this problem, but also the practical activities, the school's student management cadres around the school talent training goal, bold practice, to reform the management work of students in Colleges and universities also made beneficial exploration to the cable, accumulated a lot of experience, but there are still many problems, the lack of theoretical and systematic research. The pattern of higher education has been from the elite of to mass began to change and higher education also more and more matured, modernization, the dominant position of the students in the management gradually improve, people-centered philosophy of education is being accepted. Under this condition, the original school management education mode cannot meet the requirements of the times; therefore, the study of the student's management mode is very important.

\section{Basic content of new mode of student management work}

\subsection{New mode of student management work}

In the higher education reform and the promotion of quality education, higher education is developing from the elite education mode to the popularization of education mode. Therefore, in the University Counselors' student management work, the method, the angle, the direction, the goal, the concept has the very big change, need to carry on the unceasing innovation research. The student's management mode of the traditional college counselors can't adapt to the new era condition. Therefore, under the new situation, to achieve the change of the new philosophy of education innovation and management ideas and methods, which makes the relationship between students and instructors have also been great changes, this is the student management of college counselors under the new situation of the new model, this model can be simply expressed as "Education management service development". As shown in Figure 2.1: 


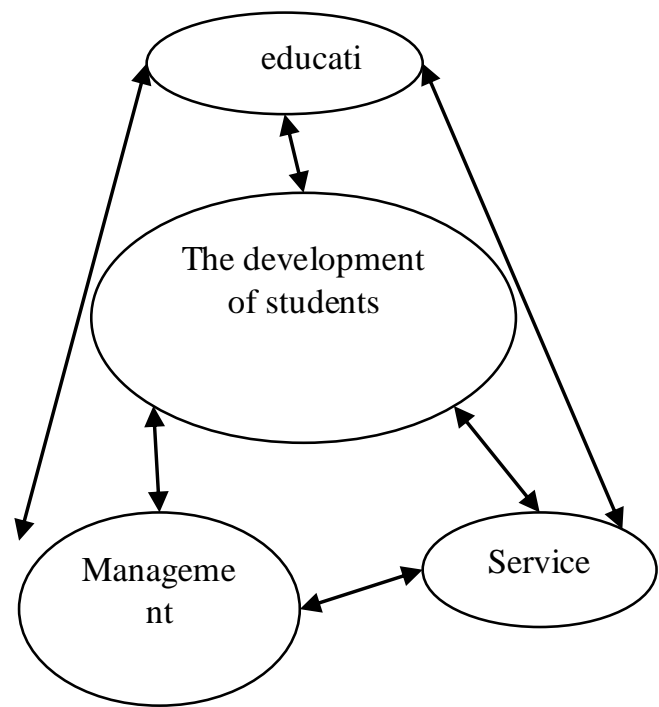

Fig2.1 New education management service mode

\subsection{Basic content of new mode of student management work}

Under the new situation of counselors in Colleges and universities students management new pattern refers to the students as main body, which can fully realize the student's own development, so a new difference from traditional mode of the new model. The introduction of such management mode, in fact, put the concept of people-oriented to the educational management mode. In the new situation, the change of education idea fundamentally changed the mode of university student management, and changed the purpose, method and means of management.. In the new mode, students are the most important subject, in order to give full play to the students' subjective initiative as the fundamental requirements, so that education reached the level of respect, equality.

Firstly, this pattern concentrates on the function of subjective initiative and the main body status of students in management mode, not the object of domination.. Second, the foothold of this new model is the new situation, people-oriented concept, highlighting the importance of developing students' own potential. Third, the transformation of this mode is the transformation of the thinking mode, the transformation of the college counselors in the management of the thinking is the most critical part of the. In this way, in the daily management process can make the students' potential to maximize the play, realize the full balanced development of students, achieve the purpose of people-oriented education. Finally, this is also a way of work of innovation. In the management mode of traditional college counselors did not emphasize the student's role, but only mandatory requirements and methods to reach the purpose of student management, the suppression of the development of students' personality, the individual's needs. In the new management mode, the instructor should promote the students' comprehensive development, improve the students' initiative and realize the harmonious development.

\section{Main features of the new mode of student management}

\subsection{Interactivity}

In the new management mode, the basic content is that students can choose their own direction and interest according to their own characteristics. This has greatly improved the degree of attention to the individual differences; each person can develop in accordance with their own suitable direction and not a unified target. It can also be understood that in the planned economy era, the market can not play its own initiative, relying solely on the national macro-control to achieve the established target. And such economic policies, so that the economic entities cannot adjust to their own actual situation to find the most suitable for their own way, denied the individual, differences. However, this way, for the economic development, it is obvious that more harm than good. However, under the condition of market economy, the main emphasis is on the adjustment mechanism of the market itself, which makes supply and demand reach equilibrium state. So, this mode of management is the objective and supervisor to decide, is the real choice of history.

\section{2 sufficiency}

The most important interpretation of the new situation is to implement the people-oriented concept, the real realization of the students' individuality, the balanced development of the diversity of the students. In the network structure of "Education -- Management -- Service -- development", it is the purpose of using education and management to achieve the ultimate goal of student development. If there is no way to achieve the development of students as the basic goal, then such a management model is the most important significance. Therefore, in order to achieve the maximum difference between the traditional education modes, in the management should bring the new situation to the full play, achieve the purpose of achieving the balanced development of the students.

\section{3 services}

In the mode of education, management, service and development, the service is through the whole course, and the four main bodies are a form of service. Under the new situation, the proportion of the students in the management of the college counselors in the management of the students will become more and more important, and more and more important. In fact, the essence of college 
students management is the service of the students growing and becoming talented.. In the management process, all students, student services all, all for student services, and ultimately college students all-round development. This new pattern is not only the change of the students' main body status but also the change of the role of the counselors.. This new form of work can fundamentally achieve the goal of the new model.

\section{The construction theory and operating system of the new mode of student management}

\subsection{The principle of constructing the new mode of student management for the people-oriented}

\subsubsection{Subjectivity principle}

To attain the goal of counselors in Colleges and Universities under the new situation of student management mode reform of the most important is to the subject position of students, to implement, truly realize the students is the absolute subject of process management. And more worthy of attention is, college students are in the critical period of psychological development, self-awareness gradually, the age of the child has strong curiosity, responsibility, self-esteem, independence and so on distinct characteristics, therefore, in such a sensitive period. How to realize the university student's management, make it into the correct growth, the talent track, establish the right outlook on life, world outlook, the value outlook is particularly important. If at this time, arouse the students' psychology, will cause serious consequences.

\subsubsection{Guiding principle}

Obviously, it is important to guide the students to choose the right way and the right way if the students' main body status is to be realized.. This can also make the students truly understand the need of their own initiative under the condition of ensuring the students' subjective initiative.. Through such behavior can avoid students due to curiosity, difference and lead them astray, so completely lost the meaning of new management mode. Therefore, the appropriate guidance of the counselor is also an important prerequisite for students to play the initiative of the students.

\subsubsection{Difference principle}

Difference is the objective existence of reality, each with a different individual exist great difference. Therefore, the implementation of the management of teaching students in accordance with their aptitude is especially important. At the same time, we need to pay attention, we emphasize the differences, also can't ignore the synchronization between college students. If you emphasize the difference, it may cause the students' unbalanced development. In brief, in emphasizing the individual difference, simultaneously must take into account the overall harmony, realizes the entire student equilibrium, the harmonious development. In this way, it can make the new situation of college student's management objectives to the ultimate. Let all the students in a complete and harmonious collective to achieve the greatest degree of development of the individual.

4.2 The operating system of the new mode of building the students' management

Under the new situation, the College Counselors' student management mode is composed of different subjects, which is different from the single form of the traditional model.. Throughout the system, including the counselors, schools, families and the whole community, but more importantly, student service system, student evaluation system. The goal of the new management mode can be realized only through the coordinated development between the different parts of the system.. Such a whole organization system is advantageous to the students from family to school, from school to the society to form the complete education management system, makes the education management more comprehensive, objective and reliable.

In the system, the students' evaluation system is different from the traditional evaluation system, and pay more attention to the students' moral, value and other factors.. The students in the study, life, work in the process of attitude, personality, behavior, conduct and so on comprehensive evaluation. For the former evaluation system over the results and results, the new evaluation system more attention to the development of the students' moral character, intelligence, sports, labor and so on.. Results is not an end, but in the pursuit of the process, students can really achieve a balanced development of a comprehensive, from learning habits to the attitude to life form a complete system, with correct life outlook, values, world view.

On the basis of improving the content of the evaluation, we should pay more attention to the management and change of the implementation process.. From the form of the original single tests, quizzes, homework and transformation for the diversification of evaluation methods, such as counselors can through defense, quizzes, contests, portfolio assessment method for the evaluation of the students. This can also maximize the new model of the differences, adequacy, subjectivity. According to the situation of different students, formulate the corresponding evaluation method, in order to achieve the goal of the students' quality development. In this way, obviously, the more reasonable than the single evaluation method, far, to promote the comprehensive and unique development of students play an important role. 


\section{Conclusions}

College Counselors of student management work is an important part of the management of colleges and universities, the traditional student management work is very messy and by the shackles of the traditional mode of education, ideological, and in this way to reform brought great difficulty. This paper tries to break through the traditional management mode, so as to establish the concept, principles and system of the students management mode in the new situation.

Under the new situation, the management system of college counselors is actually the mode of education, management, service and development. Through the high degree of emphasis on the students' individuality, uniqueness, balanced development, service students, understanding students, and eventually the students will be the comprehensive talent. In this process, the most important is that the instructor through the guidance of the students, the maximum level of the students' subjective initiative. To in helping students understanding based on self promotion of the personality of the perfect and full development to "excellent excellent, usually not poor ".

\section{References}

[1] Shi qifu, Chen jianhe, "Research on student management model based on the concept of people oriented", LILUN DAOBAO,2013(5)

[2] Massimo Giannini, "Human capial and income distribution dynamics." Research Economics,2001,N055

[3] Lor.K.Leslie "Development and Education",EducationJournal,Vol.22.No.2,2

[4] Yu dongjiang, Wang yan, Yao yuan, "Application of people-oriented concept college students' management",Study of young Chinese,2009(9).

[5] Tao shaojing, " The way of design and implementation of the work of college students management system" The school part building and ideological education,2009(9) 